\title{
Cost Management at Higher Education Institutions - Cases of Bosnia and Herzegovina, Croatia and Slovenia ${ }^{1}$
}

\author{
Martina Dragija Kostić \\ University of Zagreb, Faculty of Economics and Business, Croatia \\ mdragija@efzg.hr \\ https://orcid.org/0000-0003-0131-0345 \\ Tatjana Jovanović \\ University of Ljubljana, Faculty of Public Administration, Slovenia \\ tatjana.jovanovic@fu.uni-lj.si \\ https://orcid.org/0000-0003-4528-8725 \\ Jelena Jurić \\ University of Mostar, Faculty of Economics, Bosnia and Herzegovina \\ jelena.juric@ef.sum.ba \\ https://orcid.org/0000-0002-2731-059X
}

Received: 16. 10. 2018

Accepted: 25. 1. 2019

\section{ABSTRACT}

Higher education expenditures persistently rise due to various economic, demographic and socio-cultural reasons. This caused repeated calls for reforms of the economic model in the higher education sector and dramatically increased the importance of the economic evaluations in the last decades due to concerns for efficiency. The above academic challenges led us to pioneering an attempt to evaluate the capabilities of financial management tools for three Western Balkan countries, i.e. Bosnia and Herzegovina, Croatia and Slovenia. The precondition for successful reform processes is certainly a comprehensive and high-quality accounting information system that meets not only the requirements of external reporting but also the requirements of internal users, especially the management of HEls. In that context, the main aim of this paper is to overview the legal and organizational accounting systems' characteristics focusing on external and internal reporting requirements, and study the level of development and usage of cost accounting at HEls in selected countries. Therefore, our paper employs research methodology based on the survey conducted. The results show great differences in legal and organizational characteristics of accounting systems among the countries

1 This article is a revised version of the paper entitled "Cost management at higher education institutions - case of Bosnia and Herzegovina, Croatia and Slovenia" presented at the CIGAR 2018 Workshop, Zagreb, July 5-6, 2018. The CIGAR contributions are not publicly available. 
as well as in the development stages of cost accounting systems, which mainly focus on inconsistent overhead allocation as well as different accounting basis usage. The research results confirm poorly conceptualised and structured reporting of accounting information for management purposes, offering several applicable platforms for creation of performance management approaches and strategies in the public sector.

Keywords: cost management, financial accounting, higher education institutions, accrual accounting, Bosnia and Herzegovina, Croatia, Slovenia

JEL: $123, M 41$

\section{Introduction}

Forced by marketization, the phenomenon of massive expansion of higher education, several governments have coped with the challenge of HEls efficiency, while the existing resources cannot meet the demand. The increasing number of students entering the higher education system and the inability of the public resources to finance this massive expansion, the increasing cost-sharing with parents and students, the public call for accountability and sustainability demand new resources but also efficient and effective service delivery at the existing level (Molesworth et al., 2010; Abbott and Doucouliagos, 2003).

The accurately determined public policy of higher education system demands the improvement of the financial management objectives focusing on providing high quality accounting information (Sanyal and Martin, 2009). Although HEls register the business transactions and prepare the financial reports according to the accounting rules that are prescribed by the normative framework, those systems provide insufficient information for performance management. Instead, accounting systems do not transparently present the different revenue sources on which universities rely, the true costs of core functions such as teaching and research, the cross-subsidies of some functions by others, administrative growth or shrinkage, and differences among disciplines. All of the above-mentioned data prevents managers from making wise decisions (Capaldi and Craig, 2011).

The higher education system is a community of people implementing institutional goals: education through educational activities and innovations through research activities (Del Sord et al., 2012, p. 826). Due to mentioned public HEls have a key role for social and economic development of any country and they are deemed to be responsible for use of public funds for financing their own activities (Ibid, 2010, p. 826). For this reason the higher public education institutions are included in the whole set of different financial and institutional reforms in order to achieve financial stability, institutional autonomy and quality measurement (Kyvik, 2004; Sursock and Smidt, 2010, p. 395). Modern public HEls can face with problem of spreading services and difficulties caused by increase of costs that will affect their financial stability 
(Simmons et al., 2006, p. 31). To successfully achieve the mentioned reform process it is necessary to have appropriate cost accounting system and use of cost information through this system.

Cost accounting ensures important source for financial accounting in the manner of ensuring cost data for determination of financial position (Khan and Jain, 2007). Recommendation for public HEls is to implement accounting methods and techniques of private sector through accounting information system (Mitchell, 1996, p. 53). This is possible by using accrual basis in public higher education institutions. An accrual basis has a key role in understanding values of assets and costs (Agasisti et al, 2015, p. 496; Jovanovic, 2015, p. 68) and in increasing financial responsibility, transparency and efficiency of public HEls (Christiaens and Rommel, 2008, p. 61). Accrual accounting basis implementation in financial accounting became specific movement in public sector in the previous 20 years (Mehrolhassani and Emami, 2013, p. 281). This is related with the New Public Management movement (Drechsler, 2009) that emphasises accounting reforms in public sectors by introducing measurement of effectiveness and managerial control of entities in the public sector (Eriotis et al. 2011, p. 154). According to Wynne (2004) advantages of accrual basis are comprehensive financial data, better assets management, calculation of full price of public services, focus on output, better quality of information for management and decision making, better comparability results that could lead to development of responsibility accounting in the public sector.

Financing of public HEls refers to financing of educational activity, research and costs of students' support (scholarships, subsidies and supports) as well as capital investment in infrastructure (Letica and Dragija, 2014, p. 80). The last financial crisis affected the HEls in the sense of smaller funds necessary for the proper functioning of the institutions. For this reason, it can be seen that public HEls need to comprehend all incurred costs. The European University Association (EUA) promotes the use of full costing method as basis for cost calculation. The full costing refers to ability to identify and calculate all direct and indirect costs of an institution's activities including projects (Estermann and Claeys-Kulik, 2013, p. 6). The costs of universities' activities are rising and hence the financial sustainability have to be concern for universities in the 21st century. The first step towards this is to identify the real costs of their activities (Pruvot et al, 2015, p. 6). Monitoring the total costs of their own activities becomes very significant for HEls if they want to be financially sustainable based on timely and transparent information decision making.

The full costing method has been developed and applied relatively recently, since 1990s (Hutto, 2009). Tatikonda and Tatikonda (2001, p. 26) emphasized that full costing method ensures more accurate information on total costs and this enables more efficient allocation of limited resources and more efficient control of costs, i.e. it can be seen accurate picture on total costs and their holders. Cropper and Cook (2000) upgraded full costing concept by activity based costing methodology as the most significant costing innovation in higher education. The EUA in their report from 2013 emphasised that the 
European universities are faced with numerous funding challenges that has to be overcome and following of full costs can help in it. According to this report (Estermann and Claeys-Kulik, 2013, p. 12) full costing has certain benefits for universities: a more systematic approach to activity analysis and costing, a more efficient internal resource allocation, improved strategic decision-making based on better understanding of investment decisions, benchmarking possibilities within the sector and an enhanced ability to negotiate and price activities. Full costing is relatively new accounting approach. Hence, there are still many obstacles to its implementation. The EUA's report from 2013 mentions few of them as main: lack of autonomy, legal barriers and lack of trust between stakeholders, lack of financial support for implementation of full costing. Full costing is seen as an instrument that helps universities to provide better input for decision-making process, ensure a more systematic analysis of activities and costs, provide better opportunity for negotiations and support price formation, ensure more effective distribution of inner resources and enable comparison (Toompuu, 2015, p. 36). By full costing of universities Toompuu (2015, p. 36) refers to the ability to identify and calculate all direct and indirect costs per activity and/or project that need to be considered to carry out these activities. The same author also indicates that there are some general principles that has to be taken into account in implementing full costing: it should respect diversity of systems, missions, profiles and funding and governance structure, different costing models. ABC offers framework but allows different options for activities, cost drivers, cost objects and resources, different time allocation mechanism (Toompuu, 2015, p. 37).

The developed European higher education institutions have recognized the importance of comprehensive accounting information bases and have implemented cost methods that provide full cost information for individual activities at HEls (Estermann and Claeys-Kulik, 2013). Thus, there are different approaches of the development of full costing at HEls that depend on the institutional profiles and strategies of higher education institutions. The common feature of all approaches is the focus on identifying and calculating all direct and indirect costs by individual activities, programs and projects of higher education institution. Nevertheless, the implementation of the full costing method is a prerequisite for the efficient management at higher education institutions.

In accordance with the problem exposed, the article is focused on the following coherently connected research objectives:

- overview of the legal and organizational accounting systems' characteristics for HEls focusing on external and internal reporting requirements in observed countries;

- analysis of the cost accounting systems capabilities in HEls in observed countries. The analysis consists of four research areas: a) cost tracking area, b) allocation of indirect cost (overheads), c) service/program price

price determination; d) methods of cost calculation. 
The paper is divided into five sections. After a brief introduction, the methodology is presented, followed by results of legal and organizational characteristics of accounting systems in different countries comparison as well as comparison of development stage of cost accounting systems in HEls. After the discussion part in the fifth section, the conclusion is presented.

\section{Methodology}

On the basis of the presented, there are two main objectives of our study. Firstly, the research is focused on the overview of the accounting systems' characteristics using the source and literature review methodology. This method constitutes an original and valuable work of research in and of itself. Rather than providing a base for a researcher's own work, it creates a solid starting point for all members of the community interested in a particular area or topic (Paré et al., 2015).

Secondly, the research provides the precise analysis of the cost accounting systems capabilities in HEls in observed countries based on survey methodology. Within this second part of the research, there are four research questions a) how preciously can costs be tracked (at HEls as a whole, by nature types, by places of cost, by cost carriers, by sources of funding), b) do HEls allocate the indirect cost (overheads), c) how is the service/program price determined d) which methods are used for cost calculation. The selection of the methodology was adapted to the particularities of the research topic as well as to the special features of HEls. The individual perception and attitudes as well as organisational policies and practice can be assessed by the survey questionnaires (Baruch and Holtom, 2008). There are three major characteristics of research-oriented surveys, which differentiate them from according surveys as marketing tool or political polls. The purpose as first characteristic of the research-oriented surveys is to produce quantitative descriptions of some aspects of the study population, where the subject might be individuals, groups, organisations, but also projects, applications, etc. Secondly, the structured and predefined questions are a basic way of collecting information, while their answers constitute the data to be analysed. Finally, data is generally collected on the sample of study population in a way to be able to generalise the findings to the population (Pinsonneault and Kraemer, 1993).

The was conducted in the year 2015 and 2016 by using questionnaires in all public HEls in Bosnia and Herzegovina, Croatia and Slovenia. The questionnaires were sent by email in an online form and as well by post to heads of accounting. The response rate for questionnaire in Bosnia and Herzegovina (Federation of Bosnia and Herzegovina and Republic of Srpska, District Brčko is not included) was 35\% (7 out of total 20 public HEls), a response rate for questionnaire in Croatia was 34.61\% (36 out of total 104 public HEl's) and response rate for questionnaire in Slovenia was $46 \%$ (23 out of 50 public HEls). On the provided data, the descriptive statistics have been calculated providing reliable method for research objectives achievement. 


\section{Results}

\subsection{Overview of the legal and organizational accounting systems' characteristics}

The research results of the legal sources and literature considering accounting systems' characteristics in observed countries enabled presentation and disclosure of the similarities and differences of accounting systems in three observed countries. This observation included general review of the higher education systems focusing on organizational and financing level, number of entities, etc., but also comparison of the normative framework, the accounting principles, the set of external and internal financial reports of HEls.

It has been found out that the higher education systems in all three observed countries is very similar as far as organizational structure is concerned. In all three countries, the higher education sector is under the jurisdiction of ministries of education, which means the general government sector authority. The central state-level Bosnia and Herzegovina includes two largely autonomous entities: the Federation of Bosnia and Hercegovina and Republika Srpska (RS) and a self-governing district, Brcko, under the direct authority of the central state government. The limited responsibilities of the central state include the establishment of a Constitutional Court, a Commission for Displaced Persons, a Human Rights Commission, a central bank, public corporations to manage and operate transport and telecommunications, a Commission to Preserve National Monuments and a system of arbitration. In addition, in subsequent years ministries of justice, security and defence were created at state level. Institutional picture of educational sector in Bosnia and Herzegovina is a reflection of the constitutional order defined by the Constitution of $\mathrm{BiH}$, entities and cantons constitutions and District Brčko statute. According to the mentioned full and non-divided jurisdiction in the education belongs to the Republika Srpska (RS), ten cantons in the Federation of Bosnia and Herzegovina $(\mathrm{FBiH})$ and the District Brčko. Federal ministry of education and science has jurisdiction for organisation of educational sector in the $\mathrm{FBiH}$, while in the RS that jurisdiction is within the RS Ministry of education and culture (Branković, 2012). In Croatia and Slovenia, the higher education sector is under the jurisdiction of ministries of education, which means the general government sector authority.

According to the size and number of HEls criterion, our research is limited on Republika Srpska (RS) and the Federation of Bosnia and Herzegovina (FBiH). $\mathrm{HEls}$ in $\mathrm{FBiH}$ are established in accordance with the Framework Law on higher education and Cantonal law on higher education, depending on the location of HEl's establishment. The accounting regulations' jurisdictions depends on sectoral affiliation (public or private) but also "integration factor". At fully integrated universities, the faculties are organisational units (members), but only university is legal entity and the beneficiary of a budget funds. Those, integrated, universities are in the system of treasury, providing them use of the Treasury Main Book and Treasury Single Account. At non-integrated uni- 
versities every single member (faculty) is legal entity and has possibility for non-treasury activities and disposal of its own revenues (Dragija et al., 2015, p. 116). In FBiH, there are 21 organization of high education; 6 public universities (University of Sarajevo, University of Zenica, University of Bihać, University of Tuzla, University, Džemal Bijedić and University of Mostar), nine private universities and six private high schools.

In the RS all HEls are established in accordance with the Law on higher education as non-profit institutions, specifying universities as entities with independent legal personality and faculties as the organizational units (members) of the universities without legal personality. Thera are two public universities, seven private universities and ten private high schools.

HEls in Croatia are established as public or private institutions. Public HEls are organized as budgetary users while private are organized as non-profit organizations or companies. Similar to organizational structure of $\mathrm{FBiH}$, in Croatia there are two kind of universities; integrated and non-integrated universities. While non-integrated universities have "constituencies"; these are independent entities (faculties, academies), which independently conduct study programs, enrol students and hire teaching staff, integrated universities consist of several departments (faculties, etc.) without status of legal personality. Consequently, the business policy is centralized under university, which (among other) hires all employees of the members (faculties). Integrated universities are University of Dubrovnik, University of Pula and University of Zadar, while other universities are formally not integrated, but have a greater or lesser degree of functional integration. Overall, there are $119 \mathrm{HEls:}$ 8 public universities, 2 private universities, 68 faculties and art academies and 1 university centre at public universities, 4 private polytechnics, 11 public polytechnics, 22 private colleges, and 3 public colleges.

In Slovenia, the Higher Education Act determines the HEls as universities, faculties, art academies and professional colleges. The university is an autonomous, scientific research, artistic and educational institution of higher education with a particular status, which ensures the development of science, profession and art and through other entities (faculties, etc.) provides the educational process. The universities are legally independent entities. There are 4 public universities, which consist of 50 faculties and art academies, 48 private faculties.

The public HEls in FBiH apply International Public Sector Accounting Standards (IPSAS) according to the Law on accounting and auditing. According to the modified accrual basis, the revenues are recorded at the moment of payment (cash flow principle), while the time of accrual determines the evidence of expenses. A consolidated annual calculation of budget is based on a single annual calculation, while budgetary users are obligated to prepare interim financial reports on predicted and realized revenues and expenses during the budgetary year for the competent ministry. 
Three non-integrated universities use budget accounting but each faculty with its own legal personality makes and submit own financial reports, while consolidated reports are made at the university level. Specific case is the University of Mostar that has only summary overview instead of consolidated report since the last cannot be done because all faculties/members did not accept budget accounting yet.

The basic financial reports of the public HEls in the FBiH are: income statement, balance sheet, report on cash flow, report on capital expenditures and financing. Beside the mentioned, the following annual reports are made and submitted: the Form - Special data on salaries and number of employees, Annual report on budget execution, Annual report on investment, Report on calculated and paid contribution for protection against natural and other accidents. Besides annual reports, the public HEls are obligated to report quarterly in paper and e-form to the Ministry of finance. The quarterly financial reports include: review of incomes, revenues and financing by economic categories, expenditures and expenses by economic categories, special data on salaries and number of employees, special data on current and capital transfers, cross-classification of budget expenditures and expenses by economic and functional classification, register of transfers form the current budget reserve, register of unpaid liabilities, review of revenues, incomes, expenditures and expenses by economic categories, expenditures, expenses and transferred funds by source of financing for development projects, report on assigned cost of transfer.

The public HEls in RS also apply IPSAS since 2006, but full accrual basis is applied since 2013 for the financial reporting purposes, while the budget execution reports base on modified accrual basis. According to the modified accrual basis, the revenues are registered by payment, while expenses on accrual basis. Treasury Main Book and Treasury Single Account encompass all organizational units of public HEls, which do not prepare financial reports for each faculty, but consolidate the financial report for the university. Due to the nature of public HEIs' revenues (transfers from the budget, scholarships etc.) application of full accrual basis allows more comprehensive and realistic review of financial position. Consequently, the transparency of accounting information is increased making conditions for more accurate use of management evaluation indicators for evaluation of management.

In BiH usage of accrual accounting basis has enabled comprehensive and more realistic approach to the financial, property and revenue conditions. In addition, the transparency of the accounting information is increased and precise usage of performance ratios is enabled. However, the abovementioned can lead to conclusion that there are still evident differences between the Entities in Bosnia and Herzegovina on use of cost accounting and full costing. Differences can be tracked also in the legal basis of different use of IPSAS and different accounting basis between the Entities. External financial reports and included information are differently used in the $\mathrm{FBiH}$ and RS for different decisions. The mentioned can be caused by the organisational structure of univer- 
sities since universities in the RS are fully integrated while in the FBiH universities are integrated and non-integrated. Previous research (Lutilsky and Ćorić, 2015) showed that accountants and financial officers believe that full costing method for cost allocation of all direct and indirect costs should be developed. Issue of changes in accounting system and reforms in education system regarding use of cost accounting and use of full accrual basis within the Bosnia and Herzegovina universities makes space for further research and development.

Budgetary accounting is conducted based on the principle of double-entry bookkeeping and according to the schedule of accounts in the chart of accounts, as well as rules for recording transactions and events. Due to the fact that public HEls are budgetary users they are therefore obligated to prepare external financial reports by using modified accrual basis. Consequently, the revenues are recorded on cash basis while expenses on accrual basis (Vašiček, 2007). External financial reporting is determined as mandatory, with prescribed form, content, period, as well as liabilities and deadlines for their submission. The analytical financial reporting framework is universal and enable the consolidation of financial reports. Financial reports incorporate five statements, preciously presented in Table 1. As for the cash flows report, it is not stipulated in the normative framework and is drawn up on an optional basis. Financial reports of public HEls are based on the economic classification and contain information about following accounting categories: revenues, expenditures, receipts and expenses, assets, liabilities and sources of ownership recognized in accordance with the prescribed rules of measurement and evaluation. They are all available for public. Besides financial reports, the Croatian HEls are obligated to report about budget execution to relevant ministry and Ministry of Finance according to other classifications (by sources of financing, programs, etc.). Those budgetary reports of each public HEls are not public available but the data contained are used as consolidated financial and statistical data of relevant ministries and other government bodies.

There is no internal financial reporting or cost accounting system regulation for Croatian HEls. No doubt, that successful decision-making process needs additional accounting information contained in the internal reports. Even though some reports are prepared for internal purpose, the quality of those reports is questionable due to the fact that Croatian public HEls neither do not apply accrual basis of accounting neither cost accounting systems are regulated.

The Slovenia, the general budgetary accounting principle (accounting basis) for transactions recognition is the cash flow principle (cash received or paid paid realisations). Nevertheless, some public legal entities (public institution, agencies, institutes, chambers, etc.) use the accounting principle of a business event (invoiced realization), recognizing the revenue and expenses when a business event occurs. The specificity of the Slovenian public accounting system is a modified version of an accounting system where the main accounting principle is a cash basis and an accrual accounting basis is applied as main accounting principle only in case of particular budget users. The HEls are public institutions that belong into the group of indirect budget users keeping 
books on the uniform chart of accounts primarily using the accrual accounting basis but also cash basis².

The annual report consists of financial reports and business reports. The financial report consists of the balance sheet, the statement of income and expenses and the notes to the financial statements. Those reports should be forwarded to the Agency for Public Legal Records and Related Services (collecting and disclosing them) and to the Ministry of Science, Education and Sport. The required contributions to the balance sheet are: the report of state and movement of intangible assets and tangible fixed assets and the review of the status and trends of long-term investments and loans. The financial data should be disclosed in the notes to the financial statements publishing the criteria that were used for the demarcation of income and expense in a public service activity and the activity of selling goods and services on the market.

From the financial accounting system point of view, the Slovenian HEls have a predisposition to provide fully relevant and reliable information basis needed for making economic decisions at the micro level. But, there is no legal act considering the cost accounting in HEls and consequently the cost accounting is in charge of every single entity (university) itself.

2 According to the cash flow principle, the revenues and expenditures are recognized when the following two conditions are fulfilled: a) a business event resulting in the recognition of the revenue or expense has occurred and b) the cash or its equivalent has been received or paid or if receivables or liabilities relating to the revenues or expenses have been settled in another way without the actual cash flow (the Ordinance on Measuring and Breakdown of the Revenues and Expenditures of the Users of the Uniform Chart of Accounts). 
Table 1: Accounting and budgetary systems in $\mathrm{BiH}, \mathrm{Croatia}$ and Slovenia

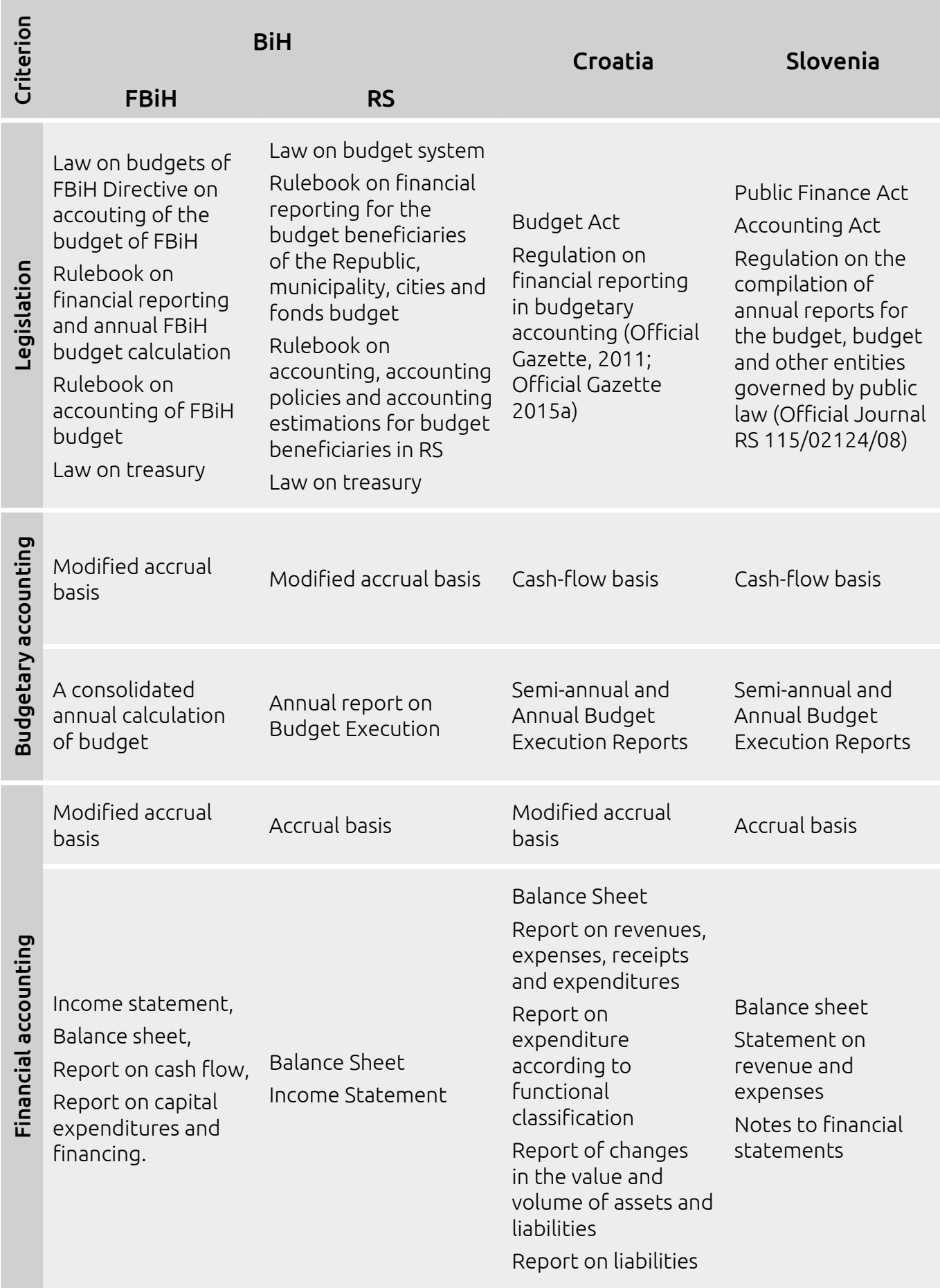

Source: own 


\subsection{Analysis of the cost accounting systems capabilities in HEls in observed countries}

In the second part of the research, the focus has centred on the analysis of the internal reporting of the HEls in observed countries, pointing out specifically cost accounting. The cost-tracking question within cost accounting is one of basic elements for useful management tool as far as decision-making is concerned. The first question of our survey was oriented on the analysis of the current situation in HEls accounting systems as far as monitoring direct and indirect costs are concerned as the potential for full costing method implementation. The results show how detail HEls are tracking cost, while in the questionnaire there were several possibilities like; a) HEls as a whole, b) by nature types, c) by places of cost, d) by cost carriers, e) by sources of funding. The results revealed that the majority of HEls do trach cost at least by places of cost, much less HEls use cost carriers or sources of funding for cost tracking.

From the Figure 1, state of the cost accounting systems at public HEls in Bosna and Herzegovina, Croatia and Slovenia can be observed.

Figure 1: Cost tracking at public HEls in selected countries

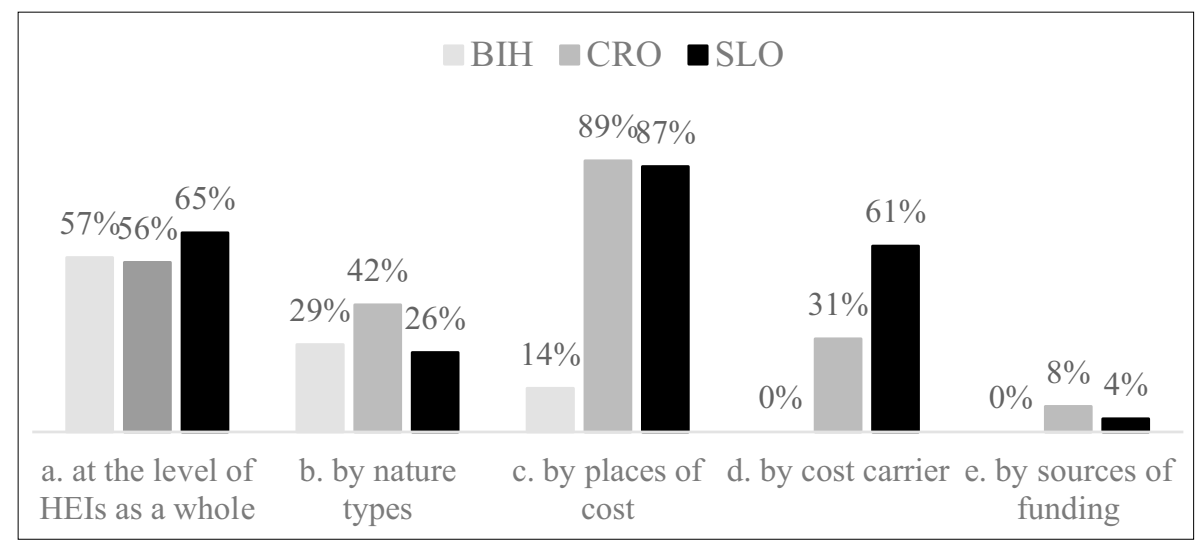

Source: own

It is evident that there are big differences in cost tracking in selected countries. In Bosnia and Herzegovina costs are dominantly tracked at the level of HEls as a whole (57\%), while by the nature types only $29 \%$ of respondents gave affirmative answer and by places of cost $14 \%$. According to research results, there is no cost tracking by cost carries and by sources of funding in Bosnia and Herzegovina. In the Croatia the most respondents answered that costs are tracked by places of cost (89\%), followed by cost tracking at the level of HEls as a whole (57\%) and by nature types (42\%). $31 \%$ of respondents in the sample is tracking cost by cost carrier and only $8 \%$ by sources of funding. The situation in Slovenia is slightly better because $87 \%$ of respondents is tracking cost by places of cost, $65 \%$ at the level of HEls as a whole and $61 \%$ of respondents is tracking cost by cost carriers. 
Allocation of indirect cost (overheads) at HEls is very important issue due to the fact that majority of HEls' costs have indirect character. In other words, those costs cannot be directly identified and allocated directly to each individual activity/project/carrier. In that context, full costing is ability to identify and calculate all the direct and indirect costs per activity and/or project. The cost accounting system that is incapable to provide information about at least direct and indirect-costs, has no potential for full cost method implementation. The fact is that the implementation of the full costing method is a prerequisite for the efficient management of HEls. The results of our second research question that are presented in Figure 2, revealed the state at HEls in three observed countries as far capability of direct and indirect cost allocation is concerned.

Figure 2: Allocation of indirect costs at public HEls in selected countries

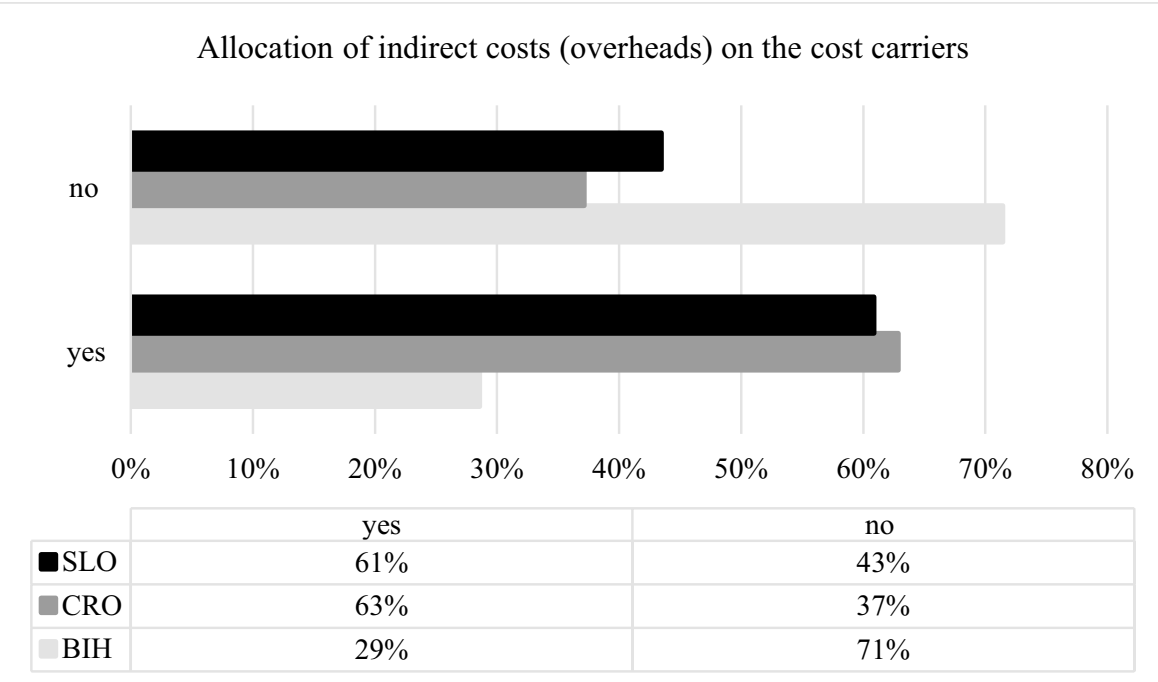

Source: own

From the Figure 2 it is evident that in Slovenia (61\%) and Croatia (63\%) most of respondents answered affirmatively on this question while in Bosnia and Herzegovina only $29 \%$. In Bosnia and Herzegovina $71 \%$ of HEls are not allocating indirect costs on the cost carriers.

HEls apply service/programme prices for several purposes. Those prices can be can be determined within the institution (management) or externally (according to legal requirements). In this context, our research question has tested the methodology HEls use for this price determination. The results are presented in Figure 3. 
Figure 3: Price determination at public HEls in selected countries

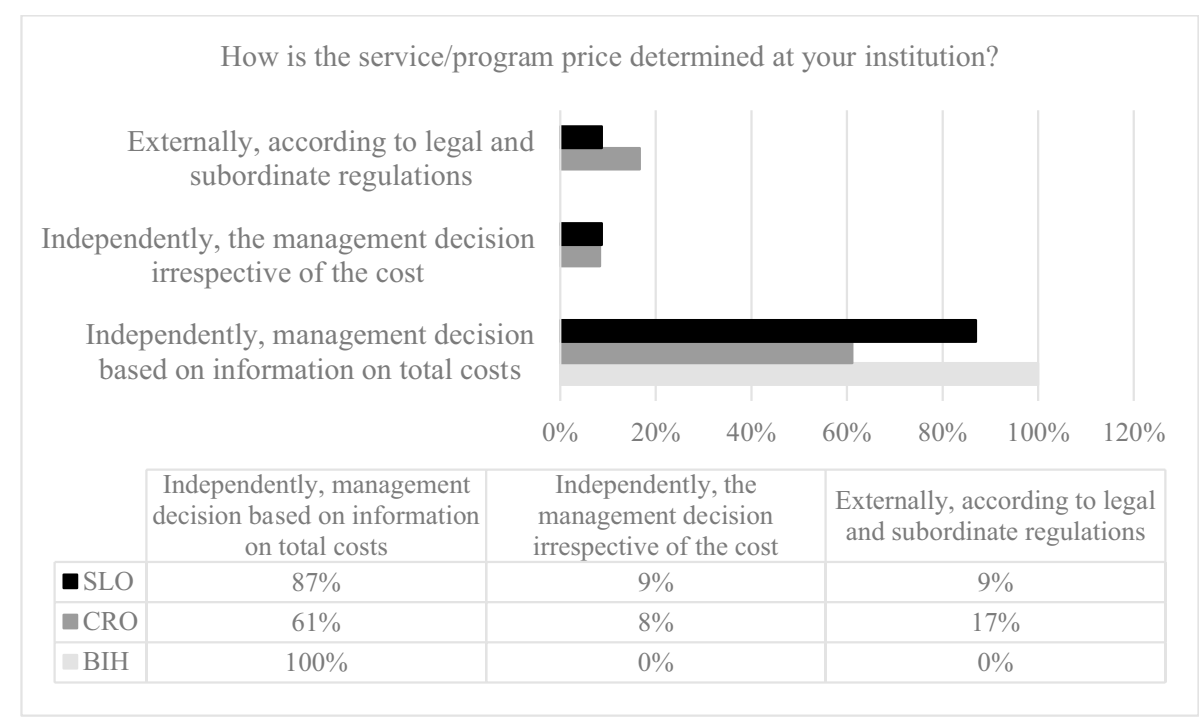

Source: own

From the Figure 3 it is obvious that in all selected countries prices at HEls are in most cases determined independently, but using accounting system information on total costs. In close connection with aforementioned question and results, the research focus has spread on determination of the calculation method to determine the prices for the services HEls independently determine. The results are presented in Figure 4.

Figure 4: Calculation methods for price determination at public HEls in selected countries

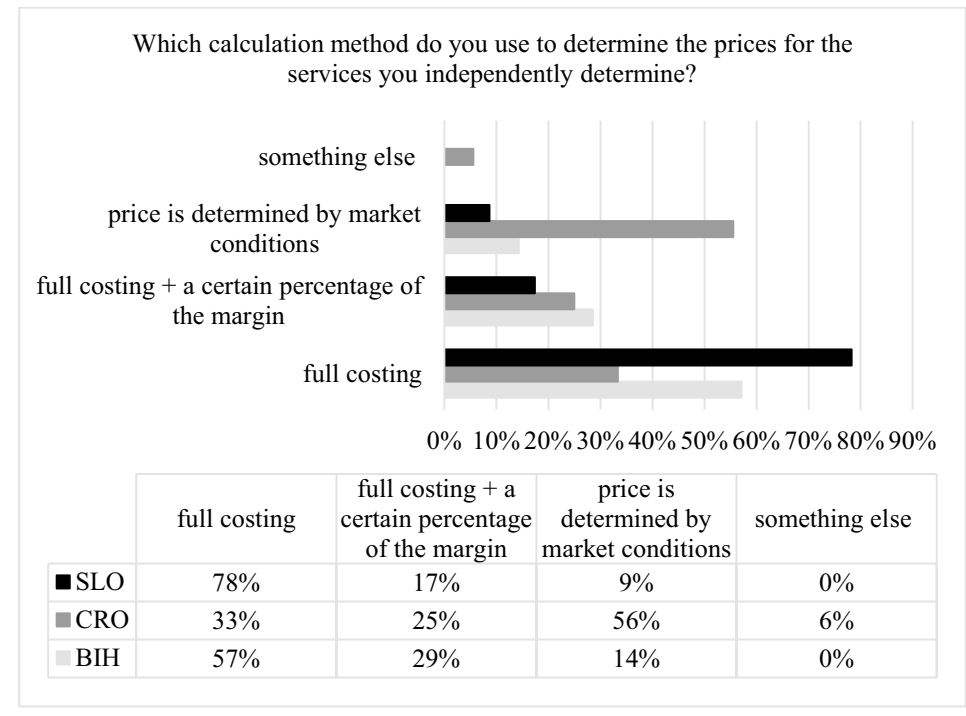

Source: own 
In Slovenia (78\%) and Bosnia and Herzegovina (57\%) respondents are dominantly using full costing method while in Croatia only $33 \%$ of respondents are using full costing method. In Croatia, most respondents (56\%) answered that the price is determined by market conditions.

\section{Discussion}

The research of the development stage of HEls' cost accounting systems in observed countries has revealed that the "accounting capacities" are primarily focused on external financial reporting, which is normatively determined due to the fact that internal reporting is at the very early development stage. The reason for such situation comes out of the fact that all three countries are ex-Yugoslavian republics with post-socialistic organizational structure of higher education. There are no available data about costs per student or programme in former common state, but it is known that 17\% of GDP has been allocated in higher education in 1989 (Latifić, 1997). The centralized financing structure of public higher education system in common state caused consequences on accounting systems of HEls that have not changed until today. The normative frameworks of public sector accounting systems in the observed countries have gone through certain reforms transforming cash flow into "more accrual" based accounting. At the moment, there are differences in the organizational structure within universities in different countries, differences in accounting principles of budgetary as well as of financial accounting and reporting. Due to the fact that $\mathrm{BiH}$ is still in the transition process with status of candidate country for EU membership, reform processes are even more intensive than in Croatia and Slovenia.

Our quantitative research revealed interesting results. In Bosnia and Herzegovina costs are dominantly tracked at the level of HEls as a whole (57\%), while in Croatia (89\%) and in Slovenia (87\%) most frequently cost are tracked by places of cost. In that context, the results of testing overheads allocation have not been surprising. It turned out that in Slovenia (61\%) and Croatia (63\%) HEls allocate overheads, while HEls in BiH did that only in $29 \%$ organizations. The smallest differences among countries have been presented as far as price determination was concerned, while the prices are in most cases determined independently by using total costs information. Considering cost methodologies in HEls differences appeared. In Slovenia (78\%) and Bosnia and Herzegovina (57\%) respondents are dominantly using full costing method while in Croatia only $33 \%$ of respondents.

All of the above mentioned, raises many new issues. Undoubtedly, the interrelation of all four questions has brought some additional insights. The fact is that overheads allocation is first step in providing cost accounting system of high quality. Having in mind that approximately $60 \%$ of Slovenian and Croatian HEls and less then $30 \%$ of HEls in BiH allocate overheads, the reliability of information about cost tracking strategies and methodologies is under great concern. How can management rely on data and information about cost if even overheads are not allocated? From that point of view, the Slovenian HEls seems to have most reliable data, while only $17 \%$ of HEls use $A B C$ method $17 \%$ and 
only $26 \%$ Balanced Scorecard. Surprisingly, the ABC method has been most frequently used in $\mathrm{BiH}$ but the reason has been found in the international project IPA Reform of Higher Education in BIH 2012-2014, where universities representatives in cooperation with EU experts developed a computer program to track the cost per student, but application of this program was on voluntary basis so it was never actually implemented in the reporting systems as mandatory part.

Nevertheless, the problem of reliability of the data obtained still remains due to the fact that only Slovenian hospitals use accrual based accounting system. Other two countries' accounting systems use modified accounting basis for cost/expenses recognition, that would on the example of depreciation mean that cost are recognized in the period when the asset is purchased and it is not divided on the useful time of the asset.

\section{Conclusion}

A comprehensive and developed accounting information system is on the most important preconditions for efficient management at HEls. The fact is that the HEls in developed countries have already recognized the importance of good management accounting systems. On the basis of financial accounting that is legally regulated, HEls worldwide have started to develop cost accounting as an important management tool. Moreover, European University Association promotes the use of full costing method as basis for cost calculation at HEls. In that context, the main aim of this paper was to investigate the level of development and usage of cost accounting at HEls in selected countries; Bosnia and Herzegovina, Croatia and Slovenia on the basis of legal framework and literature as well as on the survey conducted in the years 2015 and 2016.

The literature review and normative framework analysis of accounting systems in the observed countries have indicated that accounting systems are more oriented on satisfying legal requirements regarding reporting then on usage of cost accounting instruments for management purposes. Due to that, we have examined following areas of cost accounting in order to reveal the real level of development and usage of cost accounting tools. Results of conducted research have shown big differences in the cost accounting usage at public HEls in Bosnia and Herzegovina, Croatia and Slovenia. Overall, the cost accounting systems in the observed countries are at the very low development stage tracking indirect cost in approximately $60 \%$ of HEls in Slovenia and Croatia and less then $30 \%$ in Bosnia and Herzegovina. According to our research results, it is obvious that there are several more steps in development of the cost accounting systems of the observed countries.

\section{Acknowledgement}

This paper is a result of Croatian Science Foundation's funding of the project 8509 Accounting and financial reporting reform as a means for strengthening the development of efficient public sector financial management in Croatia. Any opinions, findings, and conclusions or recommendations expressed in this material are those of the authors and do not necessarily reflect the views of Croatian Science Foundation. 


\section{References}

Abbott, M. and Doucouliagos, C. (2003). The efficiency of Australian universities: a data envelopment analysis. Economics of Education Review, 22 (1), pp. 89-97.

Agasisti, T., Catalano, G., Di Carlo, F. and Erbacci, A. (2015). Accrual accounting in Italian universities: a technical perspective. International Journal of Public Sector Management, 28 (6), pp. 494-508.

Baruch, Y. and Brooks C. H. (2008). Survey response rate levels and trends in organizational research. Human Relations, 61(8), pp. 1139-1160.

Branković, N. (2012). The system of higher education financing in Bosnia and Herzegovina, expertise.

Capaldi, E.D. and Craig, W. A. (2011). Performance and Costs in Higher Education: A Proposal for Better Data Change. The magazine of higher learning, 43 (2), pp. 8-15.

Christiaens, J. and Rommel, J. (2008). Accrual accounting reforms: only for business like (parts of) government. Financial Accountability \& Management, 24 (2), pp. 59-75.

Cropper, P. and Cook, R. (2000). Activity Based Costing in Universities-Five Years On. Public Money and Management, 20 (2), pp. 61-68.

Del Sord, C., Orelli, R. L. and Padovan, E. (2012). Accounting practices in Italian higher education system. Economic Research, 25(3), pp. 825-845.

Dragija, M., Letica, M., and Čegar, B. (2015). Comparison of accounting Framework and Financial reporting of higher education institutions in Republic of Croatia and Bosnia and Herzegovina. Zbornik radova (Journal of Economy and Business), posebno izdanje, 2, pp. 108-132.

Drechsler, W. (2009). The rise and demise of the New Public Management: Lessons and opportunities for South East Europe. Administration, 7(3).

Eriotis, N., Stamatiadis, F. and Vasiliou, D. (2011). Assesing Accrual Acconting Reform in Greek Public Hospitals: An Empirical Investigation. International Journal of Economic Sciences and Applied Research, 4 (1), pp. 153-183.

Esterman, T. and Claeys-Kulik, A. (2013). Financially Sustainable Universities Full Costing: Progress and Practice, EUA Project. At <http://www.eua.be/ activities-services/publications.aspx>, accessed 20 May 2018.

Hutto, J. (2009). Risk Management in Law Enforcement, Applied Research project. Texas State University.

Khan, M.J. and Jain, P.K. (2007). Cost Accounting. Tata McGraw Hill Publishing Company Limited. New Delhi

Kyvik, S. (2004). Structural changes in higher education systems in Western Europe. Higher Education in Europe, 29 (3), pp. 393-409.

Latifić, I. (1997). Jugoslavija 1945-1990 - razvoj privrede I društvenih djelatnosti. Nauka i društvo Srbije: Beograd.

Law on budgets of FBiH, Official Gazette of FBiH, No.19/06, 76/08, 32/09, 51/09, 9/10, 36/10, 45/10.

Letica, M. and Dragija, M. (2014). ABC metoda u funkciji proračunskog planiranja financiranja visokog obrazovanja. Zbornik radova - Journal of Economy and Business, Special edition, pp. 51-70.

Lutilsky, I. D. and Ćorić, J. (2018). Assessing the Cost Information Usage at Higher Education Institutions-Case Study in Croatia and Bosnia and Herzegovina. 
In Economy, Finance and Business in Southeastern and Central Europe. Springer, Cham.

Mehrolhassani, H. M. and Emami, M. (2013). Change Theory foe Accounting System Reform in Health Sector: A case study of Keran University of Medical Sciences in Iran. Health Policy Management, 1 (4), pp. 279-295.

Mitchell, M. (1996). Activity Based Costing in UK Universities. Public Money and Management, 16 (1), pp. 51-57.

Molesworth, M., Scullion R. and Nixen, E. (2010). The marketization of higher education. Routledge, London.

Official Gazette. (1999). Accounting Act. No. 23/99, 30/02, 114/06.

Official Gazette. (2002). Rules on the compilation of annual reports for the budget, budget and other entities governed. No. 115/02124/08.

Official Gazette. (2011). Public Finance Act. Number 11/11, 14/13, 101/13, $55 / 15,96 / 15$.

Official Gazette. (2015). Budget Act, No. 87/08, 136/12, 15/15.

Official Gazette. (2015). Ordinance on Financial Reporting in Budget Accounting, No. 03/15, 93/15, 135/15, 2/17, 28/17).

Paré, G., Trudel, M.-C., Jaana, M. and Kitsiou, S. (2015). Synthesizing information systems knowledge: A typology of literature reviews. Information \& Management, 52(2), pp. 183-199.

Pinsonneault, A. and Kenneth, K. (1993). Survey Research Methodology in Management Information Systems: An Assessment. Journal of management information, 10(2), pp. 75-105.

Pruvot, E.B., Claeys-Kulik, A. and Esterman, T. (2015). Designing strategies for efficient funding of higher education in Europe, European University Association. At <http://www.eua.be/Libraries/publication/DEFINE_final. pdf?sfvrsn=4>, accessed 20 May 2018.

Sanyal, B. and Martin, M. (2009). Financing higher education: International perspectives. World 68, 110 (731), pp. 23-24.

Simmons, C., Wright, M. and Jones, V. (2006). Full costing of business programs: benefits and caveats. International Journal of Educational Management, 20(1), pp. 29-42.

Sursock, A. and Smidt, H. (2010). Trends 2010: A decade of change in European Higher Education, EUA. At <http://www.eua.be/Libraries/publicationshomepage-list/Trends2010> accessed 20 May 2018.

Tatikonda, L.U. and Tatikonda, R.J. (2001). Activity Based Costing for Higher Education Institution. Management Accounting Quarterly, 2(2), pp. 18-27.

Toompuu, K. (2015). The Full Costing Model and Its Implementation at Universities: The Case of Tallinn University of Technology. Thesis on Economics and Business Administration H47, TUT Press.

Vašiček, D. (2007). Državno računovodstvo u funkciji odlučivanja javnog menedžmenta: PhD Thesis. The Faculty of Economics, Zagreb, Croatia.

Wynne, A. (2004). Is the move to Accrual based Accounting a real priority for Public Sector Accounting? ACCA. At <https://www.researchgate.net/ publication/228263237_Is_the_Move_to_Accrual_Base_Accounting_a_Real_ Priority_for_Public_Sector_Accountings, accessed 20 May 2018. 